\title{
Influence of different ventilation levels on indoor air quality and energy savings: A case study of a single-family house
}

\author{
Arefeh Hesaraki ${ }^{\mathrm{a}, *}$, Jonn Are Myhren ${ }^{\mathrm{b}}$, Sture Holmberga \\ a Division of Fluid and Climate Technology, School of Architecture and the Built Environment, KTH Royal Institute of Technology, Stockholm, Sweden \\ ${ }^{\mathrm{b}}$ Construction Technology, School of Technology and Business Studies, Högskolan Dalarna, Falun, Sweden
}

\section{A R T I C L E I N F O}

\section{Article history:}

Received 24 July 2015

Received in revised form 25 August 2015

Accepted 26 August 2015

Available online 28 August 2015

\section{Keywords:}

Indoor air quality

Site measurements

Ventilation level

Energy savings

\begin{abstract}
A B S T R A C T
The influence of different ventilation levels on indoor air quality (IAQ) and energy savings were studied experimentally and analytically in a single-family house occupied by two adults and one infant, situated in Borlänge, Sweden. The building studied had an exhaust ventilation system with a range of air flow rate settings. In order to find appropriate ventilation rates regarding $\mathrm{CO}_{2}$, relative humidity (RH) and temperature as indicators of IAQ, four ventilation levels were considered, as follows: (I) A very low ventilation rate of $0.10 \mathrm{~L} \mathrm{~s}^{-1} \mathrm{~m}^{-2}$; (II) A low ventilation rate of $0.20 \mathrm{~L} \mathrm{~s}^{-1} \mathrm{~m}^{-2}$; (III) A normal ventilation rate of $0.35 \mathrm{~L} \mathrm{~s}^{-1} \mathrm{~m}^{-2}$; (IV) A high ventilation rate of $0.70 \mathrm{~L} \mathrm{~s}^{-1} \mathrm{~m}^{-2}$.

In all cases, the sensor was positioned in the exhaust duct exiting from habitable spaces. Measurements showed that, for case I, the $\mathrm{CO}_{2}$ concentration reached over $1300 \mathrm{ppm}$, which was higher than the commonly referenced threshold for ventilation control, i.e. $1000 \mathrm{ppm}$, showing unacceptable IAQ. In case II, the $\mathrm{CO}_{2}$ level was always below $950 \mathrm{ppm}$, indicating that $0.20 \mathrm{~L} \mathrm{~s}^{-1} \mathrm{~m}^{-2}$ is a sufficient ventilation rate for the reference building. The case III showed that the ventilation rate of $0.35 \mathrm{~L} \mathrm{~s}^{-1} \mathrm{~m}^{-2}$ caused a maximum $\mathrm{CO}_{2}$ level of $725 \mathrm{ppm}$; showing the level recommended by Swedish regulations was high with respect to $\mathrm{CO}_{2}$ level. In addition, measurements showed that the $\mathrm{RH}$ and temperature were within acceptable ranges in all cases. An energy savings calculation showed that, in case II, the comparative savings of the combined energy requirement for ventilation fan and ventilation heating were $43 \%$ compared with case III.
\end{abstract}

(c) 2015 Elsevier Ltd. All rights reserved.

\section{Introduction}

The main purpose of ventilation systems is to remove contaminants, create a good indoor air quality (IAQ) and decrease the risk of health problems by introducing and circulating fresh air throughout the building (Awbi, 2003; Dimitroulopoulou, 2012; Nilsson, 2007). Research by the European Union Joint Research Centre (JCR) showed that indoor pollutants are much more dangerous than outdoor air pollutants. Hence, it is essential to have a sufficient ventilation rate inside buildings where people spend approximately $90 \%$ of their time (Höppe, 2002). There are different methods of ventilating buildings, including natural and mechanical types, or a hybrid of the two types. In Sweden, more than $90 \%$ of single-family houses built before 1975 are ventilated naturally (RSNBH, 2009).

Based on the Swedish Boverket's regulations for buildings (BBR), all residential buildings should be ventilated by at least 0.5 air

\footnotetext{
* Corresponding author at: Brinellvägen 23, 10044 Stockholm, Sweden

E-mail address: arefeh.hesaraki@byv.kth.se (A. Hesaraki).
}

changes per hour (ach) of fresh air (Swedish National Board of Housing). However, in 2010 more than $37 \%$ of single-family houses and $21 \%$ of multi-family houses were found to be ventilated by less than 0.3 ach (RSNBHBP, 2010). The insufficient ventilation rate in those buildings would cause unacceptable IAQ. Based on the American Society of Heating, Refrigerating, and Air-Conditioning Engineers Standard 62 (ASHRAE-62), the definition of an acceptable IAQ is when $80 \%$ or more of the occupants express no dissatisfaction, and there are no known contaminants at harmful concentrations causing significant health risks. Therefore, in order to create better IAQ when retrofitting buildings, an energy-efficient ventilation system should be implemented, such as a mechanical supply and exhaust with heat recovery system, that is, a system to transfer heat from outgoing air to preheat incoming air (Fouih, Stabat, Rivière, Hoang, \& Archambault, 2012); or a variable air volume (VAV) ventilation system, that is, a system designed to supply fresh air based on the occupants' needs (Mysen, Rydlock, \& Tjelflaat, 2003).

In VAV systems, in contrast to the constant air volume system, the ventilation rate is varied depending on the demand. A 


\begin{tabular}{|c|c|}
\hline \multicolumn{2}{|c|}{ Nomenclature } \\
\hline ach & air change rate per hour, $\mathrm{h}^{-1}$ \\
\hline BBR & Swedish Boverket's building regulations \\
\hline $\mathrm{CCO}_{2}$ & $\begin{array}{l}\mathrm{CO}_{2} \text { concentration in room above outdoor level, } \\
\mathrm{ppm}\end{array}$ \\
\hline$C_{i}$ & $\begin{array}{l}\text { decipol, perceived IAQ polluted by } 1 \text { olf and venti- } \\
\text { lated by } 10 \mathrm{Ls}^{-1} \text { of outdoor air }\end{array}$ \\
\hline $\mathrm{CO}_{2}$ & carbon dioxide \\
\hline$c_{p}$ & specific heat capacity of air, $1005 \mathrm{~J} \mathrm{~kg}^{-1} \mathrm{~K}^{-1}$ \\
\hline$D_{h}$ & degree hours per year, ${ }^{\circ} \mathrm{C}$ h year ${ }^{-1}$ \\
\hline$E_{\mathrm{vent}}$ & energy for ventilation heating, $\mathrm{kWh} \mathrm{year}^{-1}$ \\
\hline HVR & high ventilation rate \\
\hline IAQ & indoor air quality \\
\hline LVR & low ventilation rate \\
\hline$n$ & $\begin{array}{l}\text { the number of measurements during steady state } \\
\text { conditions }\end{array}$ \\
\hline NVR & normal ventilation rate \\
\hline olf & $\begin{array}{l}\text { pollution from one sedentary person with metabolic } \\
\text { equivalent of } 1 \text { met }\left(4.184 \mathrm{Kj} \mathrm{kg}^{-1} \mathrm{~h}^{-1}\right) \text { with } \\
\text { hygienic standard equivalent to } 0.7 \mathrm{bath} \mathrm{day}^{-1}\end{array}$ \\
\hline PPD & predicted percentage dissatisfied, \% \\
\hline $\mathrm{PPD}_{\mathrm{CO} 2}$ & $\mathrm{CO}_{2}$ level-based PPD \\
\hline PPD $_{\text {vent }}$ & ventilation rate-based PPD \\
\hline ppm & parts per million \\
\hline$q$ & ventilation rate, $\mathrm{m}^{3} \mathrm{~s}^{-1}$ \\
\hline \multicolumn{2}{|c|}{$q_{\text {vent,person }}$ ventilation rate per person, $\mathrm{Ls}^{-1}$ person ${ }^{-1}$} \\
\hline$Q_{\text {ventloss }}$ & specific ventilation heat loss, $\mathrm{WK}^{-1}$ \\
\hline $\mathrm{RH}$ & relative humidity, \% \\
\hline SD & standard deviation \\
\hline VAV & variable air volume \\
\hline VLVR & very low ventilation rate \\
\hline VOCs & volatile organic compounds \\
\hline$x_{i}$ & measured data \\
\hline$x_{m}$ & mean value of measured data \\
\hline$\rho$ & air density, $1.2 \mathrm{~kg} \mathrm{~m}^{-3}$ \\
\hline
\end{tabular}

VAV system is used with the aim of finding a balance between IAQ and energy savings (Shan, Sun, Wang, \& Yan, 2012). Typically, the controlled variable indicating IAQ is the carbon dioxide $\left(\mathrm{CO}_{2}\right)$ level (Emmerich \& Persily, 1997). $\mathrm{CO}_{2}$ is a good indicator of the acceptability of IAQ since the exposure to $\mathrm{CO}_{2}$ corresponds directly to the number of people present and the amount of unpleasant human odours generated based on their activity level (Standard Guide for Using Indoor Carbon Dioxide, 2012; BergMunch, Clausen, \& Fanger, 1986; Cain et al., 1983; Iwashita, Kimura, Tanabe, Yoshizawa, \& Ikeda, 1990). It should be noted that the $\mathrm{CO}_{2}$ level in residential buildings is not harmful for human health, and is used only as an indicator of IAQ. $\mathrm{CO}_{2}$ becomes a dangerous pollutant at concentrations exceeding 5000 parts per million (ppm) (Threshold Limit Values for Chemical Substances, 2011), causing symptoms such as headaches, dizziness, shortness of breath, and anxiety (Clements-Croome, 2008). This level seldom occurs in residential buildings.

In addition to the VAV system providing sufficient fresh air and better IAQ it also saves energy as less outdoor air has to be handled, that is, heated, cooled, or dehumidified. The concept of VAV has been known since the 1970s; however, some barriers such as cost, complexity and unreliability of sensors have delayed this system from becoming popular (Stipe, 2003). Nevertheless, recent technologies showed VAV is now cost-effective, together with simple and reliable control. Due to more unpredictable variations and high occupancy, however, VAV is a more common solution in large assembly buildings, such as lecture halls, conference rooms, or theatres (Pan, Zhou, Huang, Zeng, \& Long, 2003) than in residential buildings.

Lavergea, Bosschea, Heijmansb, and Janssens (2011) assessed four types of VAV system for a single-family house in Belgium in terms of IAQ and energy savings. The control was based on the relative humidity $(\mathrm{RH})$, the presence or absence of occupants, the $\mathrm{CO}_{2}$ level, and a combination of all three strategies. The combination of all three strategies gave the highest savings, that is, $60 \%$; however, the strategy with the $\mathrm{CO}_{2}$ level control showed a significant reduction in peak exposure to metabolism-related pollutants. Pavlovas (Pavlovas, 2004) evaluated three modes of VAV for Swedish multifamily buildings. The control modes were based on the $\mathrm{CO}_{2}$ level, the $\mathrm{RH}$, and occupancy detection. The results showed that controlling the ventilation rate according to the $\mathrm{CO}_{2}$ level caused both acceptable IAQ and high energy savings. Nielsen and Drivsholm (Nielsen \& Drivsholm, 2010) proposed a simple method of VAV for a single-family house in Denmark. In their method, the ventilation rate varied between two levels based on the difference between the $\mathrm{CO}_{2}$ levels and moisture content of the exhaust air and the supply air. The upper air flow rate level was set as a minimum required flow rate by Danish building regulations, and the lower level was set based on indoor air quality standard EN 15251. Their in-site measurements showed that $37 \%$ of the time the ventilation rate decreased to a lower rate while keeping the $\mathrm{CO}_{2}$ level and moisture levels within an acceptable range. This value corresponded to $23 \%$ savings in ventilation heating demand, and 35\% lower ventilation fan consumption.

The application of VAV systems in a recently built single-family house was theoretically investigated by Hesaraki and Holmberg (2015). Their results showed that decreasing the ventilation rate from 0.375 to $0.100\left(\mathrm{~L} \mathrm{~s}^{-1} \mathrm{~m}^{-2}\right)$ during un-occupancy from 8:00 until 18:00 may result in unacceptable volatile organic compound (VOC) concentration levels at 18:00 when people arrive home. This was due to high emissions of VOCs from building materials during the early years after construction. Therefore, to improve IAQ regarding VOC concentrations, the suggestion was to increase the ventilation rate for two hours before the home was occupied, that is, during 8:00-16:00. Compared with a constant ventilation rate of $0.375 \mathrm{~L} \mathrm{~s}^{-1} \mathrm{~m}^{-2}$, this strategy caused savings in ventilation heating requirements and electricity consumption of the ventilation fan by $20 \%$ and $30 \%$, respectively. In older buildings, however, VOC emissions from building materials are assumed to be of no concern due to the age of the building. Therefore, in old buildings there is no need to increase the flow rate and remove VOC concentrations before people arrive home.

Shan et al. (2012) proposed and implemented a new VAV strategy with a $\mathrm{CO}_{2}$ sensor in the main return air for detecting the number of people and flow metre in each individual zone for office buildings in Hong Kong. Their results showed acceptable IAQ and up to $50 \%$ energy savings by using this VAV system. Nassif (2012) proposed a multi-zone $\mathrm{CO}_{2}$-based demand controlled ventilation for office buildings in which due to having better IAQ in critical zones the $\mathrm{CO}_{2}$ was controlled in supply air instead of return air. The results indicated up to $23 \%$ energy savings with good IAQ when using the proposed system. Pollet et al. (2013) studied the performance of a multi-zone demand-controlled ventilation in residential buildings in detail for three cities of London, Brussels and Aberdeen. The comparison was made between conventional exhaust ventilation system, heat recovery system, single-, and multi-zone demand-controlled ventilation system. Their results showed that in multi-zone ventilation systems the IAQ was significantly improved compared to other systems while reducing the primary heating energy consumption and annual fan electricity consumption by 50-65\%.

The required ventilation rates depend on both the number of people and on emissions from building materials. BBR (Swedish 
Table 1

Heated floor area per person during 2001-2013 in Sweden (Energy Statistics, 2013; Population Statistics, in press).

\begin{tabular}{|c|c|c|c|c|c|c|c|c|c|c|c|c|c|}
\hline & -01 & -02 & -03 & -04 & -05 & -06 & -07 & -08 & -09 & -10 & -11 & -12 & -13 \\
\hline Heated floor area, million $\mathrm{m}^{2}$ & 415 & 421 & 436 & 428 & 425 & 425 & 426 & 429 & 437 & 451 & 450 & 467 & 475 \\
\hline Population, million & 8.9 & 8.9 & 9.0 & 9.0 & 9.0 & 9.1 & 9.2 & 9.3 & 9.3 & 9.4 & 9.5 & 9.6 & 9.6 \\
\hline Area per person, $\mathrm{m}^{2}$ person $^{-1}$ & 47 & 47 & 48 & 48 & 47 & 47 & 46 & 46 & 47 & 48 & 47 & 49 & 49 \\
\hline
\end{tabular}

National Board of Housing) recommends two levels of ventilation rates for residential buildings: one of $0.35 \mathrm{~L} \mathrm{~s}^{-1} \mathrm{~m}^{-2}$ of floor area $(0.50$ ach in a room of height $2.5 \mathrm{~m})$ in the occupied part of the building to dilute contaminants generated by people and by building-related source pollutants; and the other of at least $0.10 \mathrm{~L} \mathrm{~s}^{-1} \mathrm{~m}^{-2}$ of floor area $(0.14$ ach in a room of height $2.5 \mathrm{~m})$ for the unoccupied parts of the building to take care of buildingrelated source pollutants. $\mathrm{CO}_{2}$ concentrations of $700 \mathrm{ppm}$ above outdoor levels have been recognised as an acceptable level for indoor $\mathrm{CO}_{2}$ (ASHRAE-62). In terms of body odour perception, this level causes $20 \%$ dissatisfaction of visitors or un-adapted persons. Referring to this acceptable $\mathrm{CO}_{2}$ concentration, the required floor area for one person can be calculated by dividing the $\mathrm{CO}_{2}$ generated by people by the ventilation rate. Mass balance calculation showed that the $\mathrm{CO}_{2}$ level reaches $700 \mathrm{ppm}$ above outdoor levels in a $32 \mathrm{~m}^{2}$ room with a height of $2.5 \mathrm{~m}$, ventilated by 0.36 ach (the difference between 0.50 and $0.14 \mathrm{ach}$ ), and polluted by one person generating $0.02 \mathrm{~m}^{3} \mathrm{~h}^{-1}$ of $\mathrm{CO}_{2}$ during rest and low activity work. Therefore, ventilation systems in Swedish buildings are designed with consideration of one person occupancy per $32 \mathrm{~m}^{2}$. However, statistics showed that in Sweden between 2001 and 2013, on average one person occupied $47 \mathrm{~m}^{2}$ of heated area (Energy Statistics, 2013; Population Statistics), see Table 1. Therefore, it is obvious that in most residential buildings, ventilation rates set based on the designated population density causes energy to be wasted on conditioning unnecessary outdoor air and also on electric energy for the ventilation fan.

The focus of this study is on the Swedish building regulations which, as shown by the statistical investigations in this study, assigned a higher ventilation rate than is actually needed in most residential buildings. We chose a case study building in order to investigate the IAQ and the potential of energy savings when the ventilation rate is adjusted based on the number of people instead of having a normal rate recommended by regulations.

\subsection{Description of the building}

We chose a single-family house with $100 \mathrm{~m}^{2}$ living area on two floors, built in the 1950s, and located in Borlänge in the central part of Sweden (see Fig. 1). Two adults and one infant, representing half a person, were living in this building. Therefore, during experiments the number of occupants of this building varied between two (before the child was born) and two-and-half, considering

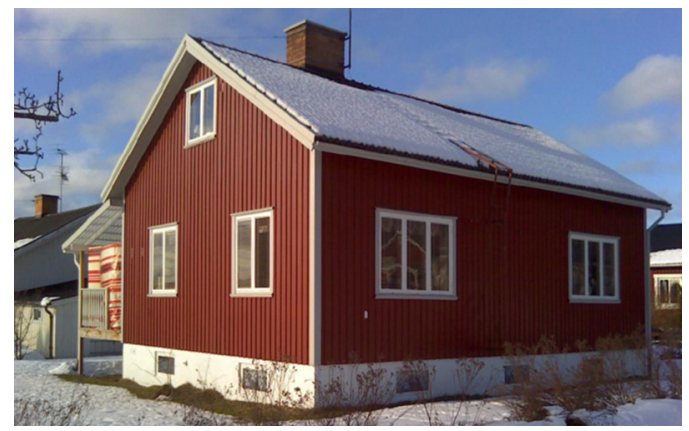

Fig. 1. The two-storey single-family house in Borlänge selected for the study. both parents and infant. This building was recently renovated in terms of installing better windows with less leakage, and adding more insulation internally with a low heat transfer coefficient ( $U$ value). Therefore, the building had low infiltration rate compared to other buildings of the same age. In addition, the heat source of this building was changed from a fossil fuel furnace to a $6 \mathrm{~kW}$ ground-source heat pump. In the central exhaust ducts of ventilation system, exhaust ducts from habitable spaces, including living room and bedrooms, were added. The purpose was to measure IAQ indicators from habitable spaces.

\section{Method}

We used two methods in this study - an experimental approach and a mathematical model. For different ventilation rates, we measured $\mathrm{CO}_{2}$ level, temperature and $\mathrm{RH}$ as indicators of IAQ and performed an experimental investigation of ventilation fan electricity consumption. The ventilation fan electricity consumption was also used to double-check the ventilation flow rate using the diagram in the device manual that shows the power consumption of ventilation fan in relation to system pressure and airflow. In addition, we used analytical models to investigate energy savings of ventilation heating demand, and predicted percentage dissatisfied (PPD) related to $\mathrm{CO}_{2}$ level and ventilation rate.

\subsection{Measurements}

The mechanical exhaust ventilation system in the case study building could be set to different levels of flow rates. Based on the assigned flow rate, the speed of the exhaust ventilation fan was adjusted accordingly. We set four airflow levels for the ventilation system, as shown in Table 2 . In case I, the ventilation rate was set at $0.10 \mathrm{~L} \mathrm{~s}^{-1} \mathrm{~m}^{-2}(0.14 \mathrm{ach})$, this being considered a very low ventilation rate (VLVR), corresponding to the minimum required ventilation rate in the BBR (Swedish National Board of Housing). In case II, we used a ventilation rate below the recommended ventilation rate set by BBR for an 'occupied' building, that is, $0.20 \mathrm{~L} \mathrm{~s}^{-1} \mathrm{~m}^{-2}$ $(0.30 \mathrm{ach})$, this being considered a low ventilation rate (LVR). For case III, the flow rate was based on a value recommended by BBR for an 'occupied' building, that is, $0.35 \mathrm{~L} \mathrm{~s}^{-1} \mathrm{~m}^{-2}(0.50 \mathrm{ach})$, this being considered a normal ventilation rate (NVR). In case IV, we used a high ventilation rate well above the recommended level, that is, $0.70 \mathrm{~L} \mathrm{~s}^{-1} \mathrm{~m}^{-2}(1.00 \mathrm{ach})$, this being considered a high ventilation rate (HVR).

The indoor $\mathrm{CO}_{2}$ level, temperature and $\mathrm{RH}$ are never uniform throughout a room (Seppänen, Fisk, \& Mendell, 1999). Therefore, to detect a mean value, the sensor should be placed either in the breathing zone, or in the exhaust valve. In this study, the latter was chosen, and the sensor was placed in the exhaust removing pollutants from habitable spaces. For different flow rates, the 'Testo 480 IAQ Probe' was used to measure IAQ indicators for every ten minutes. The accuracy of this instrument for measuring $\mathrm{CO}_{2}$ levels below $5000 \mathrm{ppm}$ is $\pm 50 \mathrm{ppm}$. Regarding the $\mathrm{RH}$ and temperature, the device has the accuracy of $\pm 2.5 \%$ and $\pm 0.5^{\circ} \mathrm{C}$, respectively.

In order to consider the ventilation rate through the mechanical ventilation system alone, and thus to exclude the influence of natural ventilation through opening windows and doors, all measurements were conducted during winter. In addition, to have only 
Table 2

Different ventilation rates used in case studies involving a single-family building.

\begin{tabular}{|c|c|c|c|}
\hline Case & Ventilation rate & $\operatorname{ach}\left(\mathrm{Ls}^{-1} \mathrm{~m}^{-2}\right)$ & Deviation from reference of NVR, \% \\
\hline I (VLVR) & Very low ventilation rate & $0.14(0.10)$ & $72 \%$ lower \\
\hline II (LVR) & Low ventilation rate & $0.30(0.20)$ & $40 \%$ lower \\
\hline III (NVR) & Normal ventilation rate & $0.50(0.35)$ & $0 \%$ \\
\hline IV (HVR) & High ventilation rate & $1.00(0.70)$ & 100\% higher \\
\hline
\end{tabular}

airflow rate through habitable spaces during measurements, the exhaust duct in the bathroom was blocked, and an exhaust fan in the kitchen was not used. Furthermore, to measure the energy consumption of the ventilation fan, we installed an electric metre on the fan. The outdoor RH during winter was between 80 and $85 \%$. Also, depending on the day of experiment, the outdoor temperature varied between -5 and $6^{\circ} \mathrm{C}$.

\subsection{Uncertainty analysis}

To analyse the uncertainty integrated in the measurements, the standard deviation (SD) of variables representing statistical error was considered during steady state conditions. Since the entire population were studied, population standard deviation was used; see Eq. (1).

$\mathrm{SD}=\sqrt{\frac{1}{n} \sum_{i=1}^{n}\left(x_{i}-x_{m}\right)^{2}}$

where $n$ is the number of measurements during steady state conditions, $x_{m}$ is the mean value of measured data, and $x_{i}$ is measured data.

\subsection{Analytical model}

Indoor air quality can be quantified using the Fanger model (Fanger, 1988) regarding the olf and decipol units, which are based on odour. The olf is a quantified factor showing the strength of the source in polluting the indoor air, and the decipol gauges perceived air pollution to quantify whether the building is healthy. One olf represents the pollution from one sedentary person with metabolic equivalent of 1 met $\left(4.184 \mathrm{~kJ} \mathrm{~kg}^{-1} \mathrm{~h}^{-1}\right)$ and with hygienic standard

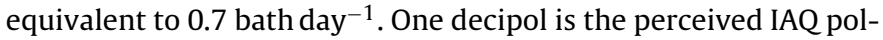
luted by one olf and ventilated by $10 \mathrm{~L} \mathrm{~s}^{-1}$ of outdoor air, that is, 1 decipol is equal to 0.1 olf $\cdot(1 / s)^{-1}$. Using these concepts, IAQ can be analysed with respect to the predicted percentage dissatisfied (PPD), based on the ventilation rate per person and the PPD of visitors (newly-introduced people) to the level of body odours, corresponding to the $\mathrm{CO}_{2}$ level above the outdoor level - see Eqs. (2), (3a) and (3b) (Indoor Air Quality \& its Impact on Man, 1992). Using ventilation rate-based PPD, IAQ can be classified as A, B, or $C$, as defined by the Commission of the European Communities, in its 'Guidelines for Ventilation Requirements in Buildings' report (Indoor Air Quality \& its Impact on Man, 1992). Category A shows a PPD lower than $15 \%$, category B from 16 to $20 \%$, and category C from 21 to $30 \%$.

$$
\begin{aligned}
& \mathrm{PPD}_{\mathrm{CO}_{2}}=395 \cdot \exp \left(-15.15 \cdot \mathrm{C}_{\mathrm{CO}_{2}}^{-0.25}\right) \\
& \mathrm{PPD}_{\text {vent }}=395 \cdot \exp \left(-1.83 \cdot q_{\text {vent, person }}^{0.25}\right) \text { for } \\
& q \geq 0.32 \mathrm{~L} \mathrm{~s}^{-1} \text { person }^{-1}
\end{aligned}
$$

$\operatorname{PPD}_{\mathrm{vent}}=100$ for $q<0.32 \mathrm{~L} \mathrm{~s}^{-1}$ person $^{-1}$

where $\mathrm{C}_{\mathrm{CO} 2}$ is the $\mathrm{CO}_{2}$ concentration in the room above the outdoor concentration ( $\mathrm{ppm}$ ), and $q_{\mathrm{vent}}$, person is the ventilation rate per person $\left(\mathrm{Ls}^{-1}\right.$ person $\left.^{-1}\right)$.
The decipol value can be calculated based on the PPD related to the ventilation rate per person - see Eq. (4) (Clements-Croome, 2008). For a healthy building, the decipol value, $C_{i}$, is less than 1 , that is, a PPD less than 15\%. A decipol value of 10 represents a sick building with more than 60\% PPD. Based on the decipol value, the indoor air quality can be classified into three categories: A for a decipol value less than 1 , B for a decipol value greater than 1.1 but less than 1.4 , and $C$ for a decipol value greater than 1.5 but less than 2.5 - see Table 3.

$C_{i}=112\left[\ln \left(\mathrm{PPD}_{\mathrm{vent}}\right)-5.98\right]^{-4}$

In addition, we calculated the specific ventilation heat loss using Eq. (5):

$Q_{\text {ventloss }}=q \cdot \rho \cdot c_{p}$

where $q$ is the ventilation rate $\left(\mathrm{m}^{3} \mathrm{~s}^{-1}\right), \rho$ is the air density $\left(\mathrm{kg} \mathrm{m}^{-3}\right)$, and $c_{p}$ is the specific heat capacity $\left(\mathrm{J} \mathrm{kg}^{-1} \mathrm{~K}^{-1}\right)$.

The degree-hours method was used to estimate the ventilation heat demand over the year - see Eq. (6). This is a simplified method for calculating the building heating demand for active heating $\left(E_{\mathrm{vent}}\right)$. The degree hours depend on the building's location and the limit temperature, which is determined by the chosen comfort temperature and the indirect/passive heat supply. The heating contribution from the limit temperature to comfort temperature is given by indirect/passive heating. In Borlänge, the degree hours $\left(D_{h}\right)$ per year is $115,080^{\circ} \mathrm{C}_{\text {h year }}{ }^{-1}$ for an assumed limit temperature of $17^{\circ} \mathrm{C}$ and a mean outdoor temperature of $4.2^{\circ} \mathrm{C}$ (Warfvinge \& Dahlblom, 2010).

$E_{\mathrm{vent}}=Q_{\mathrm{ventloss}} \cdot D_{h}$

\section{Results and discussion}

In addition to the specified ventilation rate, there was also infiltration through the building envelope in all cases. Mathematical concentration calculations based on $\mathrm{CO}_{2}$ emission from occupants and ventilation flow rate showed that around one-third of the total ventilation air was introduced into the building as infiltration. Indoor air quality parameters including $\mathrm{CO}_{2}$ concentration, temperature, and $\mathrm{RH}$ were measured for three to four consecutive days in each scenario with different ventilation rates. In this section, only the results of $24 \mathrm{~h}$ starting from 18:00 on the second day of experiments are shown. In the following subsections, the results and discussion of energy savings and IAQ are presented for each case separately.

Table 3

Indoor air quality categories based on PPD related to ventilation rate and perceived indoor air quality.

\begin{tabular}{lll}
\hline IAQ category & Ventilation rate-based PPD & Perceived indoor air quality \\
\hline A & Less than $15 \%$ & Less than 1 \\
B & Between 16 and 20\% & Between 1.1 and 1.4 \\
C & Between 21 and 30\% & Between 1.5 and 2.5 \\
\hline
\end{tabular}



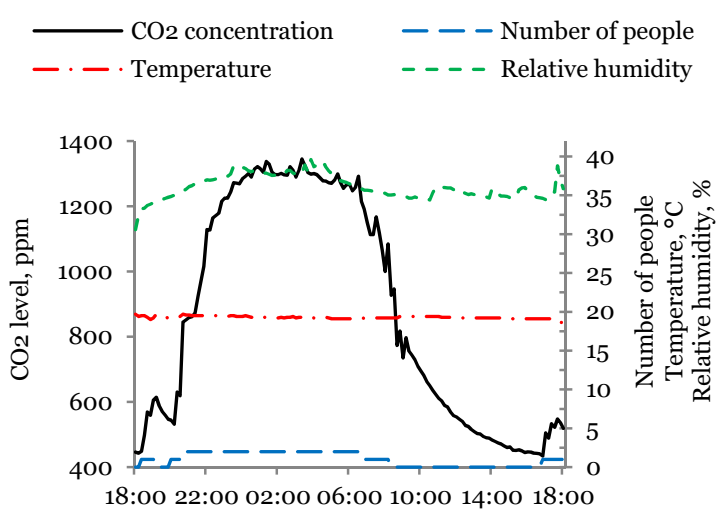

- PPD related to $\mathrm{CO} 2$ level

$-\cdots \cdot$ PPD related to ventilation rate

-..-..-- Perceived indoor air quality

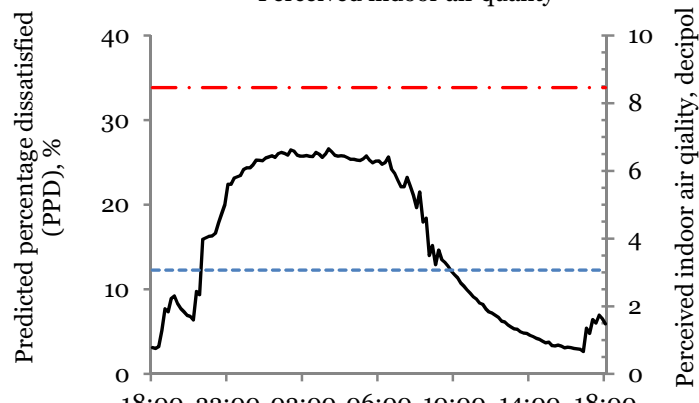

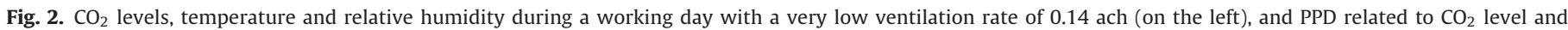
ventilation rate and perceived indoor air quality for a very low ventilation rate (on the right).

\subsection{Case I: a very low ventilation rate (VLVR)}

A very low ventilation rate scenario was set during 4 th, 5 th, and 6th February 2013 with average daily temperatures of $-5,-4$ and $-2{ }^{\circ} \mathrm{C}$, respectively. Fig. 2 (left) shows $\mathrm{CO}_{2}$ concentrations, $\mathrm{RH}$ and indoor temperature with a ventilation rate of $0.1 \mathrm{~L} \mathrm{~s}^{-1} \mathrm{~m}^{-2}$, on a working day when no one was at home during typical working hours. It can be seen that, when the occupants, that is, two adults, arrived home at around 20:00, the $\mathrm{CO}_{2}$ level increased to over $1300 \mathrm{ppm}$, a level that was maintained throughout the night. Using Eq. (3a), the ventilation rate-based PPD with 0.14 ach was approximately $34 \%$ which was not even within indoor air quality category C, for which the maximum PPD is $30 \%$. By this very low ventilation rate, however, other indicators of indoor air quality were within the acceptable ranges, that is, RH was between 31 and $40 \%$ and the average indoor temperature was $19.3^{\circ} \mathrm{C}$, see Fig. 2 (left). Fig. 2 (right) shows the PPD related to the ventilation rate and the $\mathrm{CO}_{2}$ concentration above the outdoor level based on Eqs. (2) and (3a). As Fig. 2 (right) shows, with this very low ventilation rate there was a maximum $26 \%$ dissatisfaction for newly introduced people in terms of body odour perception. Using Eq. (4), the perceived indoor air quality corresponds to 3.1 decipols - see Fig. 2 (right). This value is greater than 1 , showing that the building is not healthy and not even in category $C$. Therefore, this very low ventilation rate is not sufficient and caused rather poor IAQ with respect to the $\mathrm{CO}_{2}$ level.

\subsection{Case II: a low ventilation rate (LVR)}

During 11th-14th February 2014 with mean daily temperature of $2{ }^{\circ} \mathrm{C}$ for all four days, the ventilation rate was set to 0.3 ach in the case study building. Compared with case (I), increasing the ventilation rate to $0.2 \mathrm{~L} \mathrm{~s}^{-1} \mathrm{~m}^{-2}$ caused lower $\mathrm{CO}_{2}$ concentrations - see Fig. 3 (left). As can be seen from Fig. 3 (left), for this level of ventilation the $\mathrm{CO}_{2}$ level never exceeded 950 ppm when two adults and one infant living in this $100 \mathrm{~m}^{2}$ house. This level was lower than the commonly referenced value of $1000 \mathrm{ppm}$. In addition, as can be seen in Fig. 3 (left) the indoor temperature and $\mathrm{RH}$ were within the acceptable ranges of $20.2^{\circ} \mathrm{C}$ and $39-42 \%$, respectively. Ventilating with $0.2 \mathrm{~L} \mathrm{~s}^{-1} \mathrm{~m}^{-2}(0.3 \mathrm{ach})$, the PPD related to this ventilation rate and the perceived indoor air quality were around $18 \%$ and 1.2 decipols, respectively, which are defined under IAQ category B - see Fig. 3 (right). In addition, as can be seen in Fig. 3 (right), this ventilation level caused a maximum of around $18 \%$ feeling of dissatisfaction for a newly introduced person entering the house. Thus, this low ventilation rate is sufficient for the studied building and created acceptable IAQ. However, it should be noted that this level is appropriate when having two adults and one infant in the house, and it should be increased when more people are home.

\subsection{Case III: a normal ventilation rate (NVR)}

In the case study building, the normal ventilation rate of 0.5 ach was set during 4th-7th February 2014. This level of $0.35 \mathrm{~L} \mathrm{~s}^{-1} \mathrm{~m}^{-2}$, as the value recommended by BBR for an 'occupied' building, caused a maximum level of $725 \mathrm{ppm}$ of $\mathrm{CO}_{2}$, that is, much lower than the threshold level of $1000 \mathrm{ppm}$. Fig. 4 (left) shows the results of $\mathrm{CO}_{2}$ concentration, $\mathrm{RH}$ and temperature for 5th and 6th February 2014 with the average daily temperatures of $0^{\circ} \mathrm{C}$ and $2{ }^{\circ} \mathrm{C}$, respectively. As Fig. 4 (left) shows, $\mathrm{RH}$ and indoor temperature were
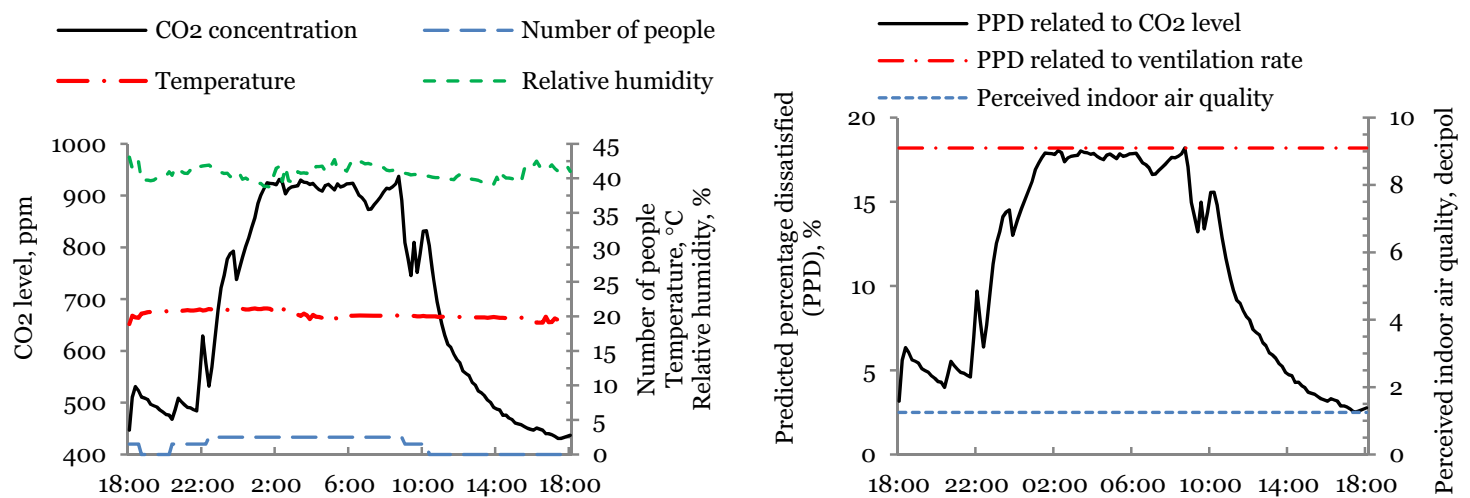

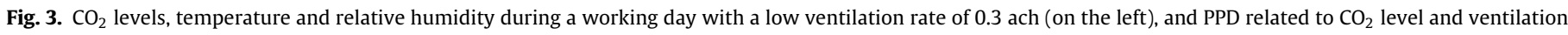
rate and perceived indoor air quality for a low ventilation rate (on the right). 

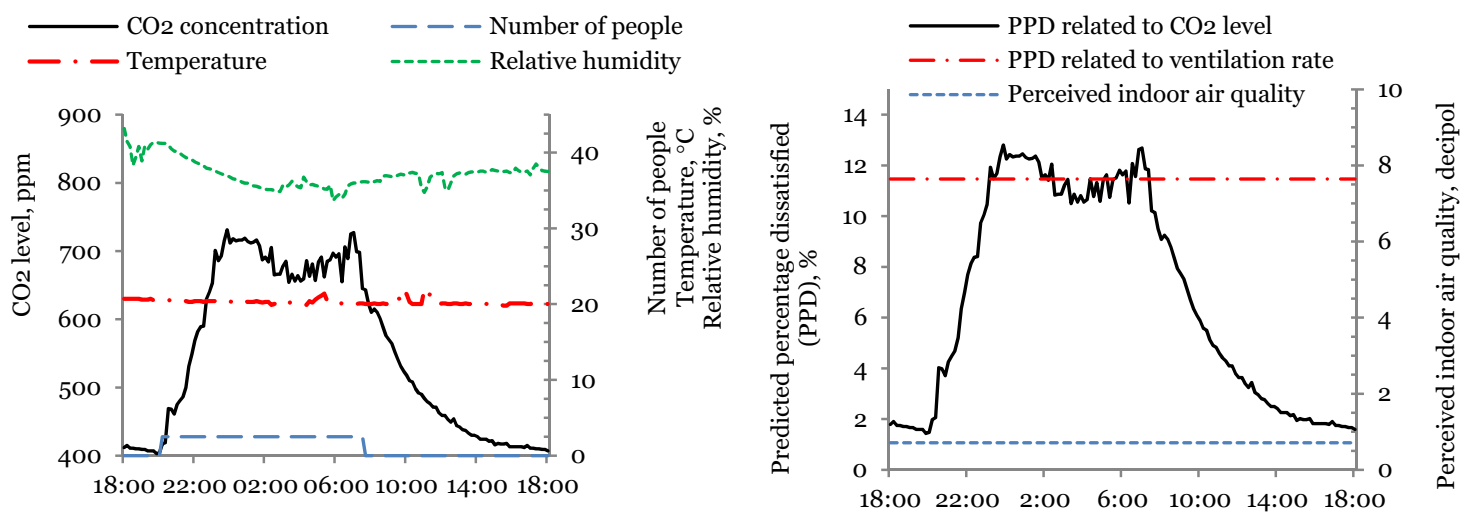

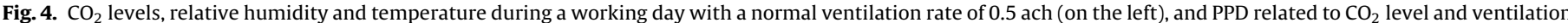
rate and perceived indoor air quality for a normal ventilation rate (on the right).
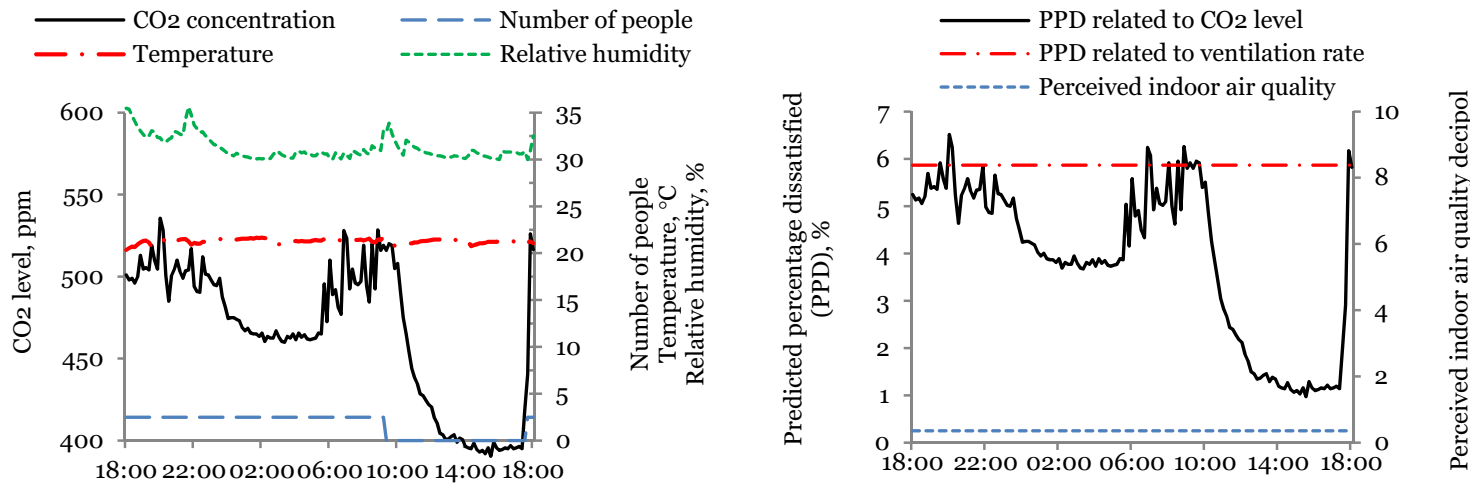

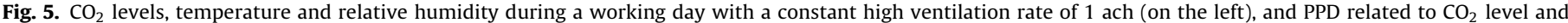
ventilation rate and perceived indoor air quality for high ventilation rate (on the right).

acceptable; that is, between 34 and $43 \%$ and $20.3{ }^{\circ} \mathrm{C}$, respectively. This ventilation strategy conformed to IAQ category A, with a PPD related to ventilation rate of $11 \%$ and a perceived IAQ of 0.7 decipols - see Fig. 4 (right). Therefore, this normal ventilation rate is too high for the studied building, and there is no need to increase the ventilation rate to the level recommended by BBR.

\subsection{Case IV: a high ventilation rate (HVR)}

This high ventilation rate was set during 7th-10th January 2015 in the case study building. This high ventilation rate of $1.0 \mathrm{ach}$, that is, $0.70 \mathrm{~L} \mathrm{~s}^{-1} \mathrm{~m}^{-2}$, caused an average $\mathrm{CO}_{2}$ level of $470 \mathrm{ppm}$ during occupancy, which was close to the outdoor $\mathrm{CO}_{2}$ level of $400 \mathrm{ppm}$. This level was much lower than the threshold level of $1000 \mathrm{ppm}$. Fig. 5 (left) shows $\mathrm{CO}_{2}$ concentration, $\mathrm{RH}$ and temperature for 8 th and 9th January 2015 with average daily temperatures of $6^{\circ} \mathrm{C}$ and $1{ }^{\circ} \mathrm{C}$, respectively. With this high ventilation rate, the mean indoor temperature was $21.3^{\circ} \mathrm{C}$, and $\mathrm{RH}$ ranged between 30 and 35\%. As can be seen in Fig. 5 (right), the PPD related to ventilation rate was $6 \%$, and the perceived indoor air quality was 0.36 decipols, corresponding to indoor air quality category A.

\subsection{Uncertainty analysis of measurements}

Calculations of uncertainty analysis were done for measurement during steady state conditions which were reached during night after occupants fell asleep; that is, constant metabolic rate with constant activity level, and constant moisture production excluding showering or cooking. Therefore, the measured data during 24:00-6:00 were used for analysis; see Table 4. As Table 4 shows, all standard deviations were within $1-3 \%$ of the average value for all parameters studied. Electricity consumption by ventilation fan was not considered in uncertainty analysis since the electric metre installed on the ventilation fan for each case showed a constant value during the entire experiment. This was due to the constant ventilation rate in each case.

\subsection{Occupants' reaction on different ventilation rates}

After measurements, occupants were asked about their opinions on different flow rates. With case I and case II, occupants did not notice any changes regarding indoor air quality and thermal comfort. However, with case III and specially with case IV, occupants felt

Table 4

Standard deviation of measured parameters.

\begin{tabular}{|c|c|c|c|}
\hline Standard deviation & Air temperature & Relative humidity & $\mathrm{CO}_{2}$ level \\
\hline Very low ventilation rate (VLVR) & $1 \%\left(0.1^{\circ} \mathrm{C}\right)$ & $2 \%(0.7 \%)$ & $2 \%(20 \mathrm{ppm})$ \\
\hline Low ventilation rate (LVR) & $3 \%\left(0.5^{\circ} \mathrm{C}\right)$ & $3 \%(1.0 \%)$ & $3 \%(30 \mathrm{ppm})$ \\
\hline Normal ventilation rate (NVR) & $2 \%\left(0.3^{\circ} \mathrm{C}\right)$ & $2 \%(0.6 \%)$ & $3 \%(22 \mathrm{ppm})$ \\
\hline High ventilation rate (HVR) & $1 \%\left(0.2^{\circ} \mathrm{C}\right)$ & $1 \%(0.3 \%)$ & $2 \%(10 \mathrm{ppm})$ \\
\hline
\end{tabular}


Table 5

$\mathrm{CO}_{2}$ levels, PPD related to IAQ and energy consumption for different ventilation rates.

\begin{tabular}{|c|c|c|c|c|c|c|c|c|c|}
\hline Case & $\begin{array}{l}\text { Air flow rate, } \\
\mathrm{Ls}^{-1} \mathrm{~m}^{-2}\end{array}$ & $\begin{array}{l}\text { Max. } \mathrm{CO}_{2} \text {, } \\
\text { ppm }\end{array}$ & $\begin{array}{l}\text { Ave. } \mathrm{CO}_{2} \text { during } \\
\text { occupancy, ppm }\end{array}$ & Max. PPD- $\mathrm{CO}_{2}, \%$ & PPD- vent, \% & $\begin{array}{l}\text { Perceived IAQ } \\
\text { decipols }\end{array}$ & IAQ category & $\begin{array}{l}\text { Energy for } \\
\text { ventilation heating } \\
\text { (fan), kWh year }{ }^{-1}\end{array}$ & $\begin{array}{l}\text { Savings (Ref. } \\
\text { NVR), \% }\end{array}$ \\
\hline I, VLVR & 0.10 & 1337 & 1231 & 26 & 34 & 3.07 & - & $1381(88)$ & 71 \\
\hline II, LVR & 0.20 & 923 & 869 & 18 & 18 & 1.24 & B & $2762(114)$ & 43 \\
\hline III, NVR & 0.35 & 725 & 648 & 13 & 11 & 0.71 & A & $4833(175)$ & - \\
\hline IV, HVR & 0.70 & 586 & 490 & 8 & 6 & 0.36 & A & 9667 (438) & - \\
\hline
\end{tabular}

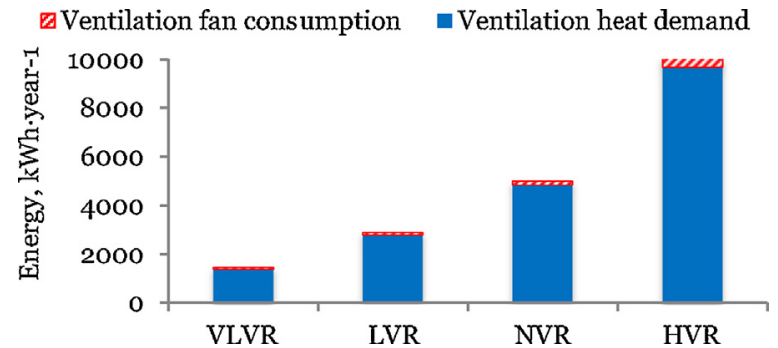

Fig. 6. Energy demand for ventilation heating and ventilation fan electricity consumption for all cases.

draft close to the building envelope. In addition, occupants detected noise problem with higher ventilation rate created by the ventilation fan, which they could hear through the ducts in the bedroom. With high ventilation rate in case IV, however, occupants were very satisfied when smell from cooking was vanished immediately.

\subsection{Energy performance}

In this study only the heat demand for ventilation system was considered, and the transmission loss was not taken into account. As the transmission loss mainly depends on the $U$ value of materials and the temperature difference between inside and outside, this limitation would not influence the energy savings comparison in different cases. Fig. 6 shows the ventilation heating demand and the electric consumption by ventilation fan for all cases studied. Considering case III as a reference case due to the level recommended by BBR, energy savings for the other cases were calculated. The energy savings for ventilation heating and ventilation fan with the VLVR were 71\% compared with the NVR. As shown in Section 3.1, however, with VLVR occupants were exposed to unacceptable indoor air quality. For case II with a LVR, energy savings for ventilation heating and ventilation fan were $43 \%$ compared with the NVR. The HVR needed almost twice as much energy as the NVR case. Reducing the ventilation heating requirement would cause savings in electricity consumption by the ground-source heat pump. As a result, the operating cost would also decrease in LVR compared to NVR and HVR. The specific fan power was $0.14 \mathrm{~W} /\left(\mathrm{m}^{3} \mathrm{~h}^{-1}\right)$ at a pressure of $100 \mathrm{~Pa}$, and with an airflow of $250 \mathrm{~m}^{3} \mathrm{~h}^{-1}$ for the fan used in the reference building. Due to this very low specific fan power, there was not a great deal of saving in terms of ventilation fan power when the flow rate was lowered. $\mathrm{CO}_{2}$ concentrations, PPD related to IAQ and energy consumption for all cases are shown in Table 5.

\section{Conclusion}

The main aim of this study was to show the overestimation of ventilation rate in Swedish building standards, BBR, in which the ventilation system is designed considering one person living per $32 \mathrm{~m}^{2}$, despite of the fact given by statistical data that one person is living per $47 \mathrm{~m}^{2}$. Therefore, it was suggested to have flexibility in ventilation levels based on the number of people and ventilation demand. Our results indicated that, for the studied building with two adults and one infant, a ventilation rate of 0.30 ach was sufficient during occupancy. This low level gave energy savings of $43 \%$ compared with 0.50 ach, while providing an acceptable IAQ. This shows the potential to save energy without harming the IAQ can be achieved by lowering the ventilation rate in a residential building based on the number of people living in the house instead of using the normal ventilation rate of 0.50 ach recommended by BBR. In case of changing family composition, the ventilation rate should be changed accordingly. The results presented in this study are only an indication of the energy savings potential if the ventilation rate is adjusted to the number of people instead of using a normal rate recommended by regulations. When more occupants are in the house, however, the upper level can be increased to more than 0.30 ach. This could be achieved by using a switch button to increase the ventilation rate to 0.50 or even $1.00 \mathrm{ach}$.

\section{Acknowledgements}

We are grateful to the Swedish Energy Agency (Energimyndigheten), the Swedish Centre for Innovation and Quality in the Built Environment (IQ Samhällsbyggnad), and SBUF, The Development Fund of the Swedish Construction Industry, for their financial support.

\section{References}

ASHRAE Standard 62.2-2007. (2013). Ventilation and acceptable indoor air quality in low-rise residential buildings. Texas: ASHRAE Standard.

Awbi, H. B. (2003). Ventilation of buildings (2nd ed.). London: Spon Press Taylor \& Francis. ISBN 0-203-63447-0.

Berg-Munch, B., Clausen, G., \& Fanger, P. O. (1986). Ventilation requirements for the control of body odor in spaces occupied by women. Environment International, 12, 195-199.

Cain, W. S., Leaderer, B. P., Isseroff, R., Berglund, L. G., Huey, R. J., Lipsitt, E. D., et al. (1983). Ventilation requirements in building: Control of occupancy odor and tabacco smoke odor. Atmospheric Environment, 17, 1183-1197.

Clements-Croome, D. J. (2008). Work performance, productivity and indoor air. In SJWEH, Suppl 4 (pp. 69-78).

Dimitroulopoulou, C. (2012). Ventilation in European dwellings: A review. Building and Environment, 47, 109-125.

Emmerich, S. J., \& Persily, A. K. (1997). Literature review on $\mathrm{CO}_{2}$-based demand-controlled ventilation. ASHRAE Transactions, 103, 229-243.

Energy statistics for one- and two-dwelling buildings in 2013. Published by Swedish Energy Agency. [Online] Available: http://www.scb.se/en_/Findingstatistics/Statistics-by-subject-area/Energy/Energy-supply-and-use/Energystatistics-for-one-and-two-dwelling-buildings/ (in Swedish).

Fanger, P. O. (1988). Introduction of the olf and decipol unit to quantify air-pollution perceived by humans indoors and outdoors. Energy and Buildings, 12, 1-6.

Fouih, Y. E., Stabat, P., Rivière, P., Hoang, P., \& Archambault, V. (2012). Adequacy of air-to-air heat recovery ventilation system applied in low energy buildings. Energy and Buildings, 54, 29-39.

Hesaraki, A., \& Holmberg, S. (2015). Demand-controlled ventilation in new residential buildings: Consequences on indoor air quality and energy savings. Indoor and Built Environment, 24, 162-173.

Höppe, P. (2002). Different aspects of assessing indoor and outdoor thermal comfort. Energy and Buildings, 34, 661-665.

Indoor Air Quality and its Impact on Man. (1992). Commission of the European Communities. European Collaborative Action Guidelines for Ventilation Requirements in Buildings. EUR $14449 \mathrm{EN}$

Iwashita, G., Kimura, K., Tanabe, S., Yoshizawa, S., \& Ikeda, K. (1990). Indoor air quality assessment based on human olfactory sensation. Jouranl of Architectural Planning and Environmental Engineering, 410, 9-19. 
172

A. Hesaraki et al. / Sustainable Cities and Society 19 (2015) 165-172

Joint Research Center (JRC), [Online]. Available: http://ec.europa.eu/dgs/jrc/index. chm

Lavergea, J., Bosschea, N. V. D., Heijmansb, N., \& Janssens, A. (2011). Energy saving potential and repercussions on indoor air quality of demand controlled residential ventilation strategies. Building and Environment, 46, 1497-1503.

Mysen, M., Rydock, J. P., \& Tjelflaat, P. O. (2003). Demand controlled ventilation for office cubicles-Can it be profitable? Energy and Buildings, 35, 657-662.

Nassif, N. (2012). A robust $\mathrm{CO}_{2}$-based demand-controlled ventilation control strategy for multi-zone HVAC systems. Energy and Buildings, 45, 72-81.

Nielsen, T. R., \& Drivsholm, C. (2010). Energy efficient demand controlled ventilation in single family houses. Energy and Buildings, 42, 1995-1998.

Nilsson, P. E. (2007). Achieving the desired indoor climate, energy efficiency aspects of system design. Lind: Studentlitteratur. ISBN-13: 978-9144032351

Pan, Y., Zhou, H., Huang, Z., Zeng, Y., \& Long, W. (2003). Measurement and simulation of indoor air quality and energy consumption in two Shanghai office buildings with Variable-Air-Volume systems. Energy and Building, 35, 877-891.

Pavlovas, V. (2004). Demand controlled ventilation: A case study for existing Swedish multifamily buildings. Energy and Buildings, 36, 1029-1034.

Pallet, I., Laverge, J., Vens, A., Losfeld, F., Reeves, M., \& Janssens, A. (2013). Performance of a demand controlled mechanical extract ventilation system for dwellings. Journal of Sustainable Design \& Applied Research, 1.

Population statistics. [Online] Available: http://www.scb.se/en_/Finding-statistics/ Statistics-by-subject-area/Population/Population-composition/Populationstatistics/
Report by Swedish National board of housing, building and planning. ISBN 978-91-86342-29-6, September 2009. [Online] Available: http://www. boverket.se/globalassets/publikationer/dokument/2009/sa_mar_vara_hus.pdf (in Swedish)

Report by Swedish National board of housing, building and planning. Technical status of the Swedish settlements - Results from the project BETSI, ISBN pdf: 978-91-86559-72-4, December 2010. [Online] Available: http://cisbo.dk/sites/ default/files/BETSI-Teknisk-status.pdf (in Swedish)

Seppänen, O. A., Fisk, W. J., \& Mendell, M. J. (1999). Association of ventilation rates and $\mathrm{CO}_{2}$ concentrations with health and other responses in commercial and institutional buildings. Indoor Air, 9, 226-252.

Shan, K., Sun, Y., Wang, S., \& Yon, C. (2012). Development and in-situ validation of a multi-zone demand-controlled ventilation strategy using a limited number of sensors. Building and Environment, 57, 28-37.

Swedish National Board of Housing, Building and planning, Boverket. [Online] Available: http://www.boverket.se/

(2012). Standard guide for using indoor carbon dioxide concentrations to evaluate indoor air quality and ventilation, United States. http://dx.doi.org/10.1520/ D6245-12

Stipe, M. (2003). Demand-controlled ventilation: A design guide. Northwest Energy Efficiency Alliance.

In American conference of governmental industrial hygienists Cincinnati,

Warfvinge, C., \& Dahlblom, M. (2010). Design HVAC systems, Lind: Studentlitteratur. ISBN: 97891440556192010 (in Swedish). 